\title{
Fostering Outstanding Personality among Teacher Trainees through ULUL Albab QEI Module Training
}

\author{
Abdel Rahman Ibrahim Suleiman Islieh ${ }^{1}$, Wan Ahmad Zakry Wan Kamaruddin ${ }^{2}$, Rossidi Usop ${ }^{3}$, Azizan \\ Harun $^{4}$, Mohd Zamrus Mohd Ali ${ }^{5}$, Mahiz Spawi ${ }^{6}$, Zulkarnin Zakaria ${ }^{7}$, Muhamad Amar Mahmad \\ 1,2,3,5,6,7 GENIUS Insan College, Universiti Sains Islam Malaysia \\ ${ }^{4}$ Faculty of Foundation and Continuing Education, Universiti Malaysia Terengganu \\ ${ }^{8}$ School of Language, Civilization and Philosophy, Universiti Utara Malaysia \\ abdelrahman@usim.edu.my*1
}

Article History: Received: 10 November 2020; Revised: 12 January 2021; Accepted: 27 January 2021; Published online: 05 April 2021

\begin{abstract}
Purpose - This study centres on a new cohort of teacher training students in Universiti Pendidikan Sultan Idris (UPSI) who were trained on the attitude and personality development modules organised by the Ulul Albab Centre in the university. The Ulul Albab modules known as QEI (Quranic, Encyclopaedic and Ijtihadik) were introduced and conducted with the participants of Ulul Albab Centre (PUA) programme. The QEI modules cover leadership talent development and soft skills which are considered as the important characteristics of outstanding personality for every future educators and community leaders. A standard questionnaire was distributed to 150 students who were pioneers of the Ulul Albab programme in the university. The participants were also asked to reflect on the various aspects and activities of the programme and modules and their written and verbal responses were analysed using NVivo 12 application. The findings indicated more than $80 \%$ approval and satisfaction rate among the participants on the constructive impact of the training on their attitude, personal and soft skills development. Their feedback and personal reflections too indicated positive bearing on their overall attitude having completed all the Ulul Albab modules. The encouraging outcomes are signs of better programme implementation for the new batch of teacher trainees. New ideas and suggestions from the participants' feedback would be integrated for the improvement of the QEI components for future cohorts and stronger plans ahead for Pusat Ulul Albab UPSI.
\end{abstract}

Keywords: Ulul Albab programme, QEI module, teacher trainees, self-development training.

\section{Introduction}

Ulul Albab was the brilliant brainchild of Dato' Seri Idris Jusoh, the former Higher Education Minister of Malaysia and former Terengganu Menteri Besar. Ulul Albab was the curriculum concept on Quranic and Islamic studies education developed to revitalise the traditional Islamic education institutions that had existed for more than 500 years ago in this country (it was reported that the school started back in 1450 in Malacca). The traditional Islamic education system in many states in Malaysia then was adopted from the Islamic and Tahfiz school system in the Middle East, India and Pakistan. The religious schools and tahfiz institutions were popularly known as "Sekolah Pondok" ('pondok' can loosely be translated as hut) and the system was already established in the country as one of the mainstream education systems available. For hundreds of years, the pondok institutions had produced generations of Islamic educated individuals who had grown into 'ulamak' and Muslim scholars and leaders in the country.

The pondok learning institutions are unique because of the humble and low-profile boarding school setting and environment. The word pondok (literally: hut) came from the Arabic word 'Al-funduq' that means "residential house, hostel, or shelter" and it is also defined as an accommodation for three or four students in a form of small houses (Fauzi, 2010; Zainal, 2020). Kamus Dewan (the authoritative DBP Malay dictionary) defined 'pondok' as a madrasa (school) or hostel which is a place to learn Al-Quran recitation and religious knowledge (Baharom, 2004). This term was assimilated and became part of the Malay vocabulary that refers to the traditional learning institutions oriented to religion (Bakar, 1992). The typical pondok would consist a row of small houses (huts) or a long house of a similar shape - the residence of the students who have come from all over the country (Ishak, 1995; Zainal, et al., 2020). Traditionally, the houses are made of wood or bamboo and erected near the home of a pious person known as "Guru", "Ustaz" or "Kiyai", who owns the madrasah, surau or mosque (Thukiman, 2002; Zainal, et. al., 2020). The main attraction to a certain pondok would be the Guru or Ustaz (religious teachers who received their education in Mecca, Egypt or India). The pondok's size and teaching staff would also become the determining factors for parents and students in choosing the pondok to study. Popular traditional pondok institutions are normally found in Patani (Southern Thailand), Kedah or Kelantan (Zailani, et al., 2018). However, the modern pondoks are more common nowadays and they are being built closer to major cities and towns unlike the traditional ones. The society are more confident in the pondok 
schools today because of their ability to produce students of high calibre and good academic achievement. For the past few decades, the government had taken the initiatives to revamp the traditional pondok system and standardise the curriculum and syllabus of religious institutions based on the modern and contemporary school system. Hence, it resulted in the birth of the Ulul Albab Islamic and Quran education system in the early millennium that marked the transformation in the national education system.

In view of the dire need to have a standardised religious school and tahfiz curriculum, the Ulul Albab education concept was planned and established in the state of Terengganu and gradually implemented in selected Imtiaz model schools managed by the state governed Yayasan Terengganu. The Quranic, Encyclopaedic and Ijtihadik (QEI) modules are the core components of the Islamic and Quran education curriculum developed to produce the future Ulul Albab generations. These QEI components are the foundation in producing and providing generation of future leaders with outstanding personality. Empowering future leaders with the essence of Ulul Albab namely the Quranic, Encyclopaedic and Ijtihadik (QEI) is the goal set under the vision of Ulul Albab education institutions. The approach is believed to offer the answers in solving various problems facing the society and global ummah.

\section{A Short History of Ulul Albab Programme}

"Ulul Albab" is the term from Quran and it is mentioned 16 times in 10 specific surahs as in (1) Al-Baqarah [2]: 179, 197, 269; (2) Ali 'Imrân [3]: 7, 90; (3) Al-Mâidah [5]: 100; (4) Yusuf [12]: 111; (5) Al-Ra'd [13]: 19; (6) Ibrâhîm [14]: 52; (7) Shâd [38]: 29, 43; (8) Al-Zumar [39]: 9, 18, 21; (9) Al-Mukmin [40]: 54 dan(10) AlThalâq [65]: 10. (Arief Efendi, 2014). The fact that the term is repeated and stressed throughout Quran underlines its importance on nation-building and the effort in generating excellent generations who are educated holistically in their physical, emotional and intellectual sphere. In Arabic, it is made of two words and defined in Al-Marbawi dictionary listed them as "ulu" and "albab". The word "ulu" means having or possessing while the word "albab" refers to pure heart, mind and soul. The word "albab" is the plural form of the an original base word "lubb" (Arshad, 2015).

The Ulul Albab programme was originally developed to groom future Muslim leaders and thinkers to lead the nation in dealing with the current issues plaguing the society and offer out-of-the-box solutions based on their great understanding and knowledge shaped by the QEI-mentality and problem-solving ability. The combination of these three components would prepare the individuals trained in this approach to understand and study the overall issue the nation and ummah are facing and prepare various potential strategies to solve the problems. The approach stresses on both individual internal strength as well as the intelligence to build the person's outstanding personality who could later act as a leader who could handle and solve all future issues (Jusoh, 2013).

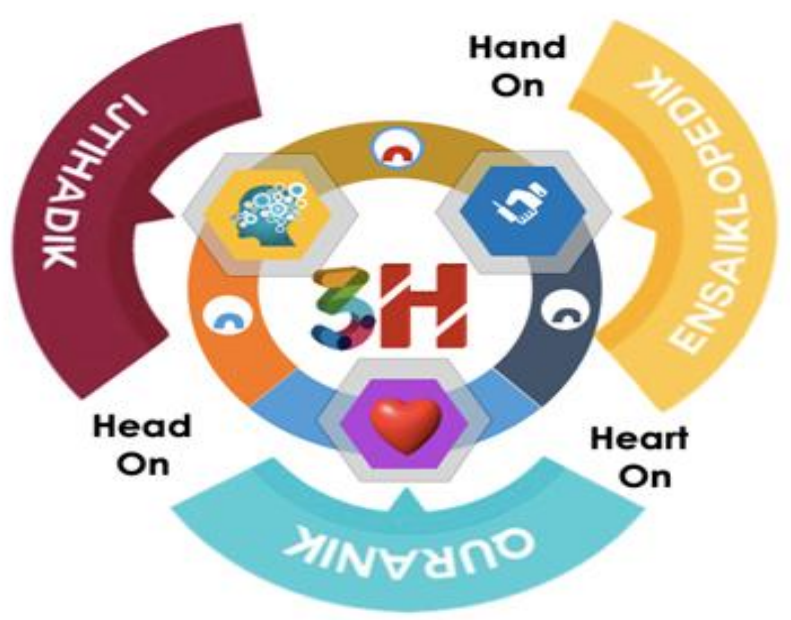

\section{G.1: Model Ulul Albab}

The three main components of the Ulul Albab concept are made of the Quranic, Encyclopaedic and Ijtihadik elements. As illustrated in the diagram, the three components are inter-related and inter-connected, and one component cannot exist without the others as it could not achieve the balance in an individual's personality in his 
life and work. Each component will exist using the connecting system of "Head On", "Heart On" and "Hand On".

The three aspects in the model cover the personality foundation that makes a person and they are the spiritual, intellectual and practical strengths needed to make one a good leader, thinker and decision-maker in life. The Ulul Albab curriculum underlines the importance of education as a catalyst to build excellent personality among the young generations who are trained in many Imtiaz Islamic academic institutions. The history of Ulul Albab and Imtiaz schools in the state of Terengganu was evidence of the success of the QEI Islamic and academic modules. The QEI approach shares the same philosophy and spirit of our very own national education philosophy that also stresses on the holistic development of a student as it covers the physical, emotional, and spiritual and intelligence elements of the person.

The Ulul Albab generations refer to future Muslim leaders, thinkers and problem-solvers who master knowledge language, science, technology and strong survival skills and ability. These features are described in the encyclopaedic part of the module. If in the past, the mastery of the third language is important, now the fourth language and so on is the element considered as very important and individual value-added skill, especially if someone wants to become a global player and compete in the international arena (Subirin et. al., 2017). In addition, qualifications and excellence in various fields also play an important role. The Ijtihadik aspect will always be the main source of strength in any society that exists today. The modern challenge facing all nations are in the mastery of technology, innovation and creativity that also play a part in the continuous development of human capabilities. This is what the Ulul Albab generations aim to get in the Ijtihadik module. They are trying to act as the trouble-shooters besides being able to lead the ummah and the nation, Malaysia.

\section{Literature Review}

The term Ulul Albab (UA) is taken from the Arabic language and in particular from the Holy Quran. The concept is an abstract idea representing the fundamental characteristics and the criterial attributes of human being. It symbolises an exceptional personality characterised by special traits such as leadership skills, critical thinking and reflection in cosmic phenomena. The concept was decided as Ulul Albab - the best choice to be the title of the education programme as it encapsulates the teaching and learning theory and a new educational system that seeks to prepare a new generation of students with an integrated personality, physically, spiritually and academically. The initial implementation was done in the secondary schools of Imtiaz and a few selected MRSM (MARA Junior Science College) and the history began in the state of Terengganu and Melaka with the Imtiaz schools and later expanded to selected religious schools in every state (Jusoh, 2013).

The humble beginning started in 1996 in Imtiaz Besut School in Terengganu initiated by a team of experts in various educational fields led by Datuk Seri Idris Bin Jusoh to prepare a new educational plan that could build the dream Ulul Albab generations. The plan was contained in the three basic elements-Quranic, Encyclopaedic and Ijtihadik modules (QEI). The quiet success of the first Imtiaz school in Besut, Terengganu triggered further expansion of the programme that included four new Imtiaz schools in other parts of Terengganu. The schools managed to achieve various great successes academically and in co-curricular activities. Using the new implemented approach, they had managed to achieve first place in the national examinations of PMR and SPM for Terengganu state level and the national level. Selected MRSM schools also managed to achieve the expected satisfactory level of success which gave good impression about this educational system using the QEI module (Zikri, 2019).

\section{QEI Concept in Ulul Albab}

QEI is an integrated educational programme prepared by experts in multiple educational fields, covering various aspects such as teaching and learning, curriculum building and planning of learning process. The Ulul Albab educational approach has been carefully based on this theory QEI (long-term educational plan and building educational curriculum, co-curriculum activities and finally educational evaluation and measurement). 


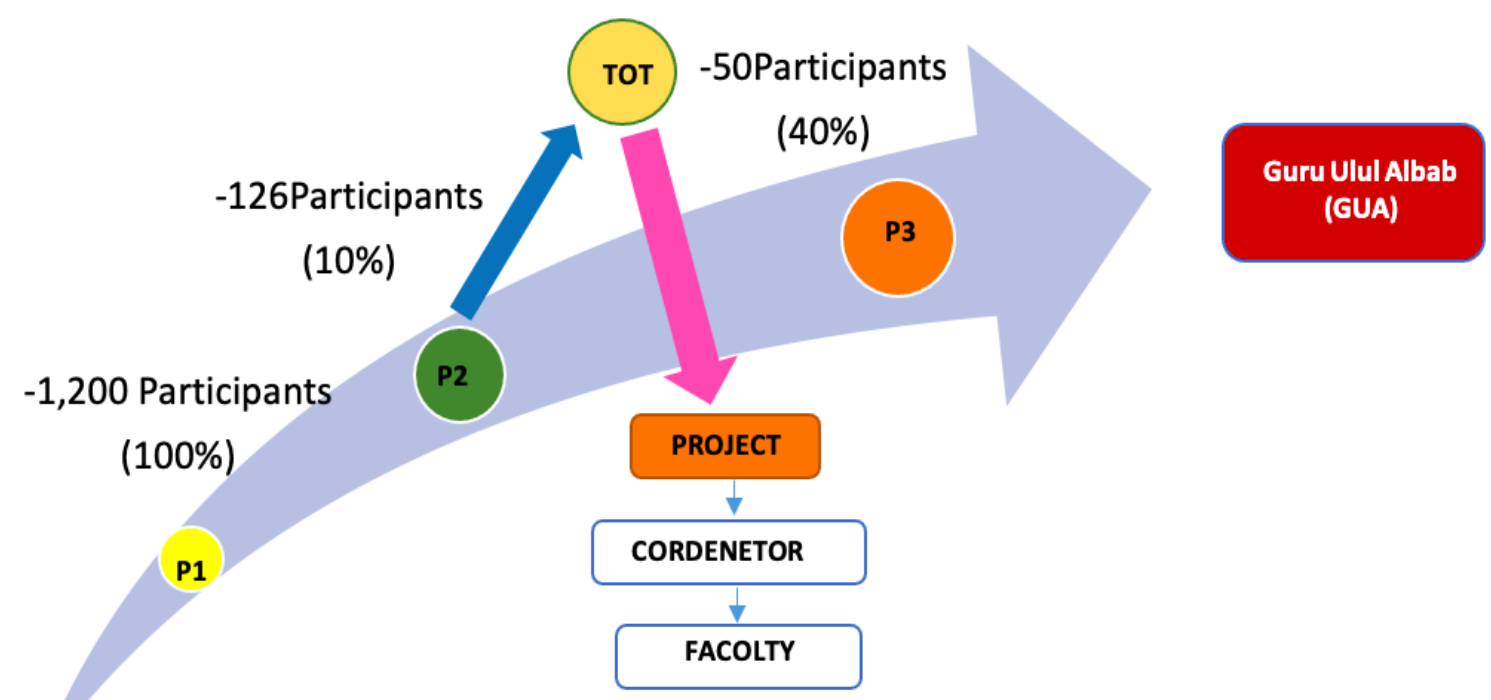

\section{G.2 : Ulul Albab Program Progress}

The main elements of the knowledge based on QEI are as follows:

Quranic: makes the Quran as a main source of knowledge in forming the heart and building positive personality, character and spiritual.

Encyclopaedic: focuses and hones the talent of communication, as well as the diversity of knowledge and other skills including foreign language also Producing a generation capable of dealing with.

Ijtihadik: prepares diversity of challenges, in addition to creative thinking and innovative and advanced technology.

This educational theory has been applied by some secondary schools and has showed successful stories in some places such as Imtiaz schools in Terengganu and Melaka, selected MRSM Ulul Albab in Terengganu and other states. This study investigated the success possibility of applying this theory among university students as the modules were further enhanced to cater the needs of tertiary level education.

\section{Research background}

After the offering of Ulul Albab programme in secondary schools in Malaysia, many researchers have conducted research and case study on the feasibility of this experiment and its ability to develop teacher trainees to be effective and professional future leaders. Many studies have shown a clear development for the candidates of Ulul Albab programme at school levels. This research focused on the first ever programme designed for university students which aim to develop qualified candidates and improve their personality and soft skills. This would be a good opportunity to gauge the effectiveness of similar programme on university students as this study set to examine the impact of the proven successful programme on university students. Therefore, the researchers decided to conduct this study on the group of first year students who have just enrolled themselves at the Universiti Pendidikan Sultan Idris.

The study aims to achieve the following objectives:

a. To analyse the impact of the Ulul Albab programme on the new batch of 2018 students at Universiti Pendidikan Sultan Idris.

b. To investigate the attitude of new students at Unversiti Pendidikan Sultan Idris towards the new Ulul Albab programme.

The research objectives were set to answer the following questions:

a. What is the impact of the QEI module on teacher trainees' attitude and personality traits, especially on the new students' intake at Universiti Pendidikan Sultan Idris? 
b. What are the reactions of the new intake students (2018) at Universiti Pendidikan Sultan Idris towards the new Ulul Albab programme?

The researchers collected the data through a questionnaire and feedback in written and oral form from the participants. Both qualitative and qualitative data was then analysed using respective applications and presented in the findings and discussion section.

\section{Methodology}

The participants of this study were the new cohort of the elementary education degree students in Universiti Pendidikan Sultan Idris (UPSI). They were identified as candidates for the first ever Ulul Albab Programme organised by Pusat Ulul Albab, UPSI. The first phase of the training allocated 500 places for the new Students. This large group was made of students from all over Malaysia and they were multi-ethnic and multicultural youth. As highlighted earlier, the UPSI Ulul Albab Programme had just been introduced to this new batch of students. The main objective of this programme is to produce generations of qualified teachers based on the QEI module approach. Initially, the actual students' number for the latest intake was 900 and they were enlisted to go through the Ulul Albab training programme. After taking many factors into consideration, the university decided to have only 500 shortlisted students for the first training programme, and they were enrolled for the various QEI training schedule throughout the semester. In the second stage, $10 \%$ of the trainees would be identified and shortlisted for the training-of-trainers (TOT) programme. Out of the total number of programme participants, $40 \%$ of them were awarded Ulul Albab Teacher Certificate for fulfilling the criteria set and attending and involving themselves in the activities and programmes throughout the academic year. For the purpose of this research, the students' sample would be taken from the TOT participants since they had shown good performance in their training and accomplished significantly in the various activities conducted.

The training attended by the new intake of first-degree students was long term training (one year, four quarters). All these participants were students in various fields of education programme (UPSI niche area). Most of them have little to no experience in teaching elementary school students. The training provided the personal development knowledge and skills these coming teachers would need to prepare them to teach subjects such as al-Quran, Arabic language and Islamic Science in elementary schools and they would get the Ulul Albab Teacher certificate to show for their accomplishment. This would be an added value for them together with the education degree they receive after completing their study in UPSI. The training modules were aimed to give basic knowledge in the QEI modules and strong understanding of teaching potentially high achiever students, and QEI methodology know-how for teaching elementary school students.

\section{Data collection}

In this mixed method study, the two data collection instruments would be a set of questionnaire and participants' written and oral feedback. In the first instrument of data collection, the questionnaire included four main sections and areas of the training proper:

Section 1: The effectiveness of training content

Section 2: The effectiveness of training performance

Section 3: The effectiveness of program trainers

Section 4: The quality of training outputs

Qualitative section: Written (comment section) and oral feedback (Course conclusion discussion)

For data collection purpose in this study, the questionnaire distributed would get respondents' information about the effectiveness of content, performance and trainers in this training. As for the second data collection instrument, the written and oral feedback from the participants would be recorded as it appeared in the feedback question included in the questionnaire as well as the oral feedback information collected at the end of each activity or programme module. The students would reflect on their learning experiences and the input they received over the course of their various sessions. The questions for both the questionnaire and reflection feedback were designed by the researchers during the Ulul Albab Research and Publication Workshop done earlier before the modules' implementation. A general frame for the set of questions for data collection was constructed for the feedback section in which each participant had to provide information on participants' need, ToT Programme content, teaching skills after completing the whole training programme and whether the training modules contributed in the participants' overall knowledge, skills, experience and personality. 
As for qualitative data, participants' written feedback was collected in the comment section included in the questionnaire. Participants also had their oral comments recorded during the concluding session at the end of every training programme. The facilitators would usually go through the different training aspects with all participants during the discussion session. Among the training areas discussed would be on the relevancy of contents, presenter, delivery method, time allocation and overall impact of the training activities at personal level. They would volunteer to give their opinions and ideas on improving or changing the training aspects so that it would become more effective in the future implementation of the programme. Their oral feedback during this session would be recorded and analysed for the general themes and specific contents pertaining to the training modules.

\section{Data Analysis}

\section{Quantitative Results}

Simple statistical analysis was applied to the questionnaire data gathered which contains four sections. Section 1: The effectiveness of training contents. The data from section 2: The effectiveness of training performance; section 3: The effectiveness of program trainers, and section 4: The quality of training outputs of the Ulul Albab modules. These sections of the questionnaire were essentially the more important sections of the study. The data from the questionnaire with four Likert Scales was analysed to draw mean to decide whether the levels of improvement after attending the training program is high, moderate or low. It was drawn based on the score measurements proposed by Katz and Kahn (1978).

\section{Quranic Module Evaluation}

The high effectiveness of the Quranic Module Evaluation with $80 \%$ percentage among the survey respondents indicated their high satisfaction and motivation in the Quranic Module. They admitted that their perception towards Quran had changed in a more positive way and they learned new and creative ways for teaching the Quran and Islamic science after attending the training programme as shown in Table 1

Table 1. Quranic Module Evaluation percentage

\begin{tabular}{|l|l|l|l|l|l|l|}
\hline Things & Contents & $\begin{array}{l}\text { Content } \\
\text { Relevance }\end{array}$ & Trainer & $\begin{array}{l}\text { Delivery } \\
\text { method } \\
\text { /Performance }\end{array}$ & Timeline & $\begin{array}{l}\text { Overall, I am } \\
\text { satisfied with } \\
\text { the Quranic } \\
\text { Module }\end{array}$ \\
\hline Satisfaction (\%) & $85 \%$ & $87 \%$ & $85 \%$ & $82 \%$ & $73 \%$ & $80 \%$ \\
\hline
\end{tabular}

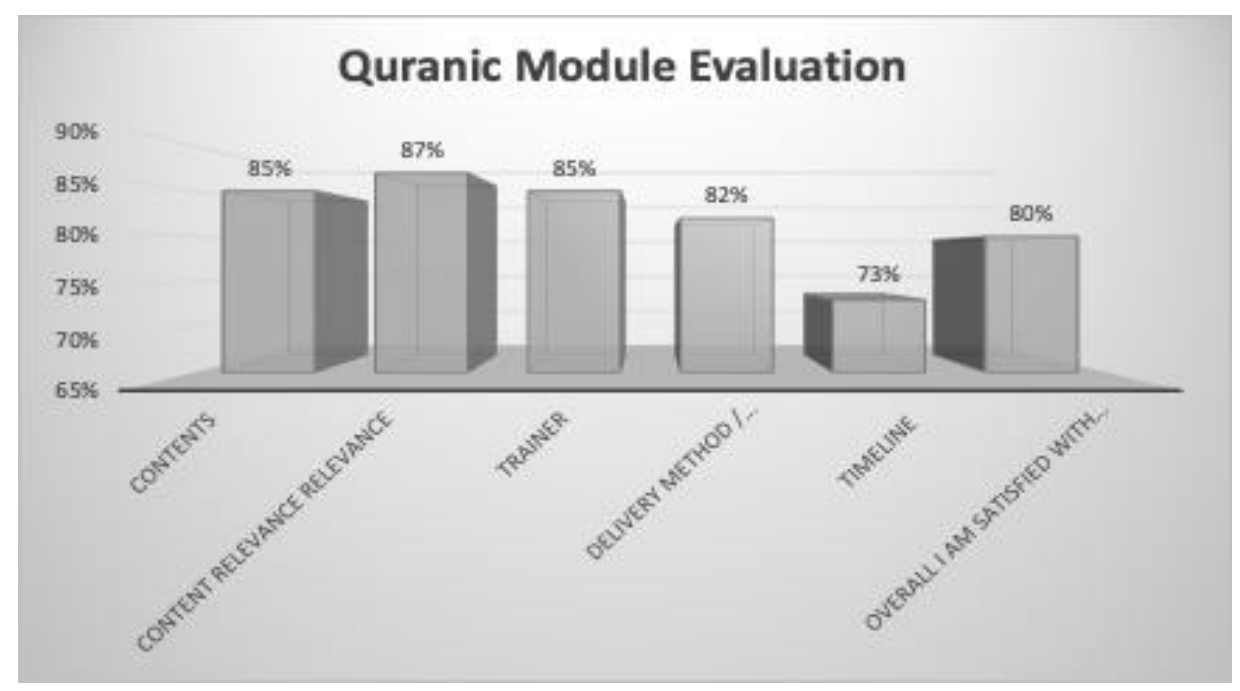

Graph 1. Quranic Module Evaluation percentage 
To justify why their motivation changed, the participants were requested to respond to the items of the Quranic Module in the questionnaire. As shown in T.1, 85\% of the participants felt that the contents were suitable to train Ulul Albab trainees and the same high rate was given to the trainer as many trainees chose the option "A suitable trainer for this Module", while $87 \%$ of them felt that the contents were relevant for what they have to teach in the elementary school level later. And this module is useful for them to be an effective Ulul Albab teacher, the timeline rated the lowest with $73 \%$ as the participants felt that the Quranic Module should be allocated more time for the slot given.

The mean score of this dimension was 4.20 and the standard deviation score was .4.19. The scores showed that the training program was highly effective to improve teacher trainees' motivation and skills in teaching Quranic Module apart of QEI Ulul Albab Model after attending the training program.

\section{Encyclopaedic Module Evaluation}

Based on the survey, the respondents felt that the basic need for the Ulul Albab teacher trainees would be learning international language such as Arabic and English and they felt that it should be given early focus in the training. The rating of $91 \%$ in the survey showed that the participants supported that the Ijtihadik module contents were equally important and they acknowledged that to begin the training with the international languages appeared to be the most important module among the components. In terms of its relevance, the Ijtihadik module was rated $90 \%$ in contents relevance, and the most applicable skill rated here was the critical and innovative thinking.

Table 2. Encyclopaedic Module Evaluation percentage

\begin{tabular}{|l|l|l|l|l|l|l|}
\hline $\begin{array}{l}\text { Programme } \\
\text { Aspects }\end{array}$ & Contents & $\begin{array}{l}\text { Content } \\
\text { Relevance }\end{array}$ & Trainer & $\begin{array}{l}\text { Delivery method } \\
\text { /Performance }\end{array}$ & Timeline & $\begin{array}{l}\text { Overall } \\
\text { satisfaction }\end{array}$ \\
\hline Satisfaction (\%) & $91 \%$ & $90 \%$ & $90 \%$ & $89 \%$ & $83 \%$ & $91 \%$ \\
\hline
\end{tabular}

For the training time allocation, the participants rated $83 \%$ for the overall Timeline score as they were claiming that the time was Not Enough, the answer followed by the choice of 'the training of this Module should be longer' while the competence of the speakers were rated under the option of 'the Trainers Are Very Qualified on how to teach and How to prepare the contents for classes," participants gave a score of $90 \%$ for Trainers but they rated the delivery method and performance (89\%) as the second lowest percentage.

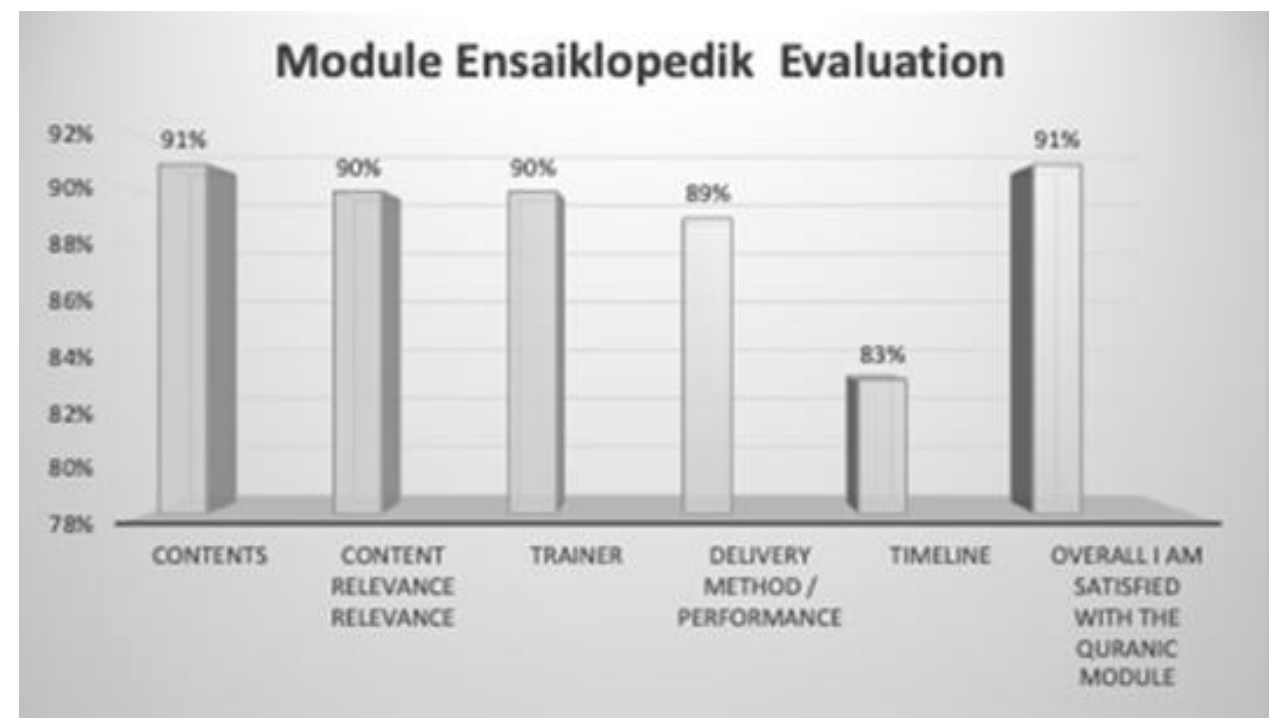

Graph 2. Quranic Module Ensaiklopedik percentage

For the Encyclopaedic module, the survey results showed that generally the respondents were equally happy with most of the training aspects. As shown in the table above, they believed that such training was beneficial and relevant for them. They also found the contents prepared in the module suited them and worked to their 
advantage. This module could help them improve as a person and perform well in their responsibility as the future teachers. The module implemented in the Encyclopaedic training program would make effective Ulul Albab teachers and experts in QEI Module. The satisfaction rate for this module was a staggering high at $91 \%$ as the participants gave their support for the implementation of this module during their training.

Table 3. Ijtihadik Module Evaluation

Ijtihadik Module Evaluation

\begin{tabular}{|l|l|l|l|l|l|l|}
\hline $\begin{array}{l}\text { Programme } \\
\text { Aspects }\end{array}$ & Content & $\begin{array}{l}\text { Content } \\
\text { Appropriateness }\end{array}$ & Trainer & $\begin{array}{l}\text { Delivery method } \\
\text { /Performance }\end{array}$ & Timeline & $\begin{array}{l}\text { Overall } \\
\text { Satisfaction }\end{array}$ \\
\hline Satisfaction $(\%)$ & $90 \%$ & $90 \%$ & $90 \%$ & $89 \%$ & $79 \%$ & $90 \%$ \\
\hline
\end{tabular}

In the summary of the table above, the scoring measurement of the participants' evaluation for Ijtihadik module was at a high level of satisfaction, similarly indicated in the previous two modules of Quranic and Encyclopaedic. Overall, the satisfaction level with the Ijtihadik Module was at averagely high $90 \%$ for many aspects of the module. The survey showed the highest score in its training content, contents appropriateness, and also the trainer's suitability rating. For the trainer's delivery method and performance score, the survey indicated the rating of $89 \%$ and the lowest score for this module was on the training timeline score with $79 \%$ score.

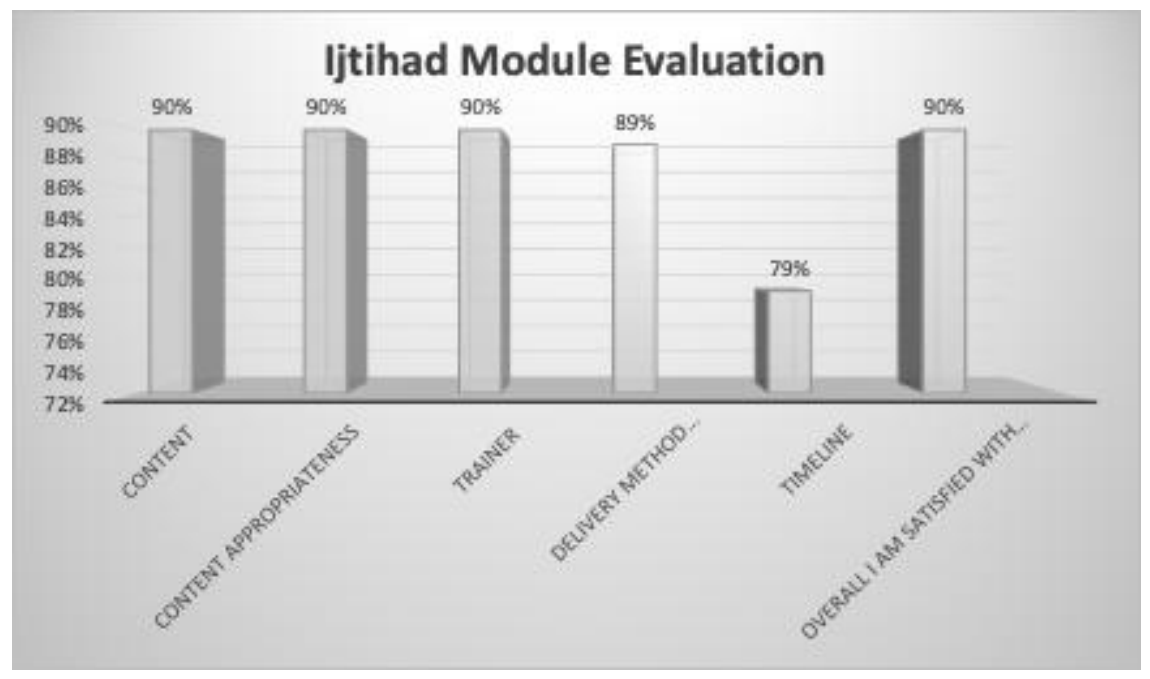

Graph 3. Ijtihadik Module Evaluation percentage

Based on the survey data collected and presented above, it can be concluded that the overall effectiveness of the Ulul Albab teacher trainees QEI training programme was positively high and effective. The respondents gave high rating in most of the training aspects asked in the questionnaire. The mean score for the all the sections was 4.18 and the standard deviation was 0.478 . From the mean score, it can be established that the effectiveness of the training program in building the participants' attitude, personality and confidence level was positively high. It was in the third range of 4.00 to 5.49 .

\section{Qualitative data analysis}

The focus on the qualitative data gained from their written and oral feedback was on the overall feelings on certain aspects of the training module and implementation. Participants had generally written their pleasure or displeasure on the training aspects such as the contents, presenter and the delivery method, time allocation and perceived usefulness of the training activities and programme.

The contents, just like the data collected in the questionnaire, indicated high level satisfaction among the participants because of the relevance of the QEI theories and knowledge presented in the training. The general themes found in their comments would be positive acceptance of the Ulul Albab training modules. Many participants wrote comments such '... good content', ‘... useful knowledge for future use ...'. Some comments also expressed their happiness and gratefulness for being the participants in the training because they could '... 
learn many new things', ‘... gain new knowledge', ‘... develop better skills and '... learn to be positive'. The expression of 'building personal confidence' was quite a popular in the written section of the feedback.

Better responses were collected in the oral feedback and discussion session at the end of training programme. Quite typical among the participants to express their gratefulness for taking part in the Ulul Albab programme. Words of praises were almost similar to the written feedback as they related their learning experience during the programme. Many of them (as shown in the high rating of $85 \%$ and above) were full of praise for learning the QEI modules as they regarded the knowledge and skills are more relevant to them who would later on become educators. The knowledge and skills are useful contents that can be applied for the young Ulul Albab generations in primary schools that they would teach once they graduated. A high percentage of participants would love to have a more allocation of training time or continuous training programme for the QEI modules. The overall sentiments pointed towards a better programme reception among the new participants provided that the suggestions and ideas shared by the pioneer programme participants are taken into consideration.

\section{Results and Discussion}

In general, most of the participants responded that the Ulul Albab training programme they attended was highly effective (with the total mean score was 4.16). From the survey, 90.9\% participants believed that the programme was successful in conveying new knowledge about approaches in QEI Ulul Albab module. The participants also agreed that the programme increased their understanding on how to implement the teaching technique using Ulul Albab approach to students of good academic achievement as shown in their $89 \%$ rating as they believed that the training programme would be applicable to elementary school students in Malaysia. Meanwhile, $80 \%$ of respondents thought the Ulul Albab programme was successful in providing new ideas for teaching elementary school students. A further $80 \%$ participants felt that the overall training could improve their classroom teaching effectiveness. A rating $90 \%$ was recorded for the question on skills acquisition during the programme that could assist the trainees to serve the students better in the future. The overall $95 \%$ rating in the questionnaire showed that participants reacted favourably to the training, highlighting many positive points. The majority of the participants also indicated (in the evaluation of questionnaire and feedback) that they had gained new skills and knowledge as a result of participating in this professional development training. For this reason, the participants supported the move by the ministry of Education Malaysia to employ Ulul Albab Teachers in all elementary schools and offer a training programme similar to this in order to produce qualified teachers in QEIbased teaching approach and develop the required skills to produce effective teaching and learning process.

In addition to the general findings, the survey also showed that $90 \%$ participants of the Ulul Albab training believed that QEI module could help them provide students with high quality education better than before they attended the training. Here, the trainees felt that after joining the QEI training, they could successfully provide interesting and useful class experience. The participants also stated that there was an improvement in their international language skills as the module trained them to be more confident in teaching language in class especially the speaking skill. The survey indicated $80 \%$ participants agreed with the statement that the training was effective in building their confidence. The total mean score was 4.18 with a standard deviation of 4.80 . In short, the training program could be claimed as successful as it met the objectives set earlier. The teacher trainees discovered that they acquired greater skills as Ulul Albab teacher-their knowledge grew and now were more confident in their ability to speak the foreign language, which would enable them to gain even greater knowledge.

Another aspect of the survey also touched on the training effectiveness in improving the trainees' motivation. The findings disclosed that the QEI Ulul Albab training programme was also highly effective in improving Ulul Albab teacher trainees in the teaching of Quran and Islamic Sciences. The mean score for this section was 4.24 and the standard deviation was 0.423. All participants agreed that the QEI training programme offered them a new method for understanding the Quran through the expert lecturer's sharing and in their feedback, they did suggest that this exposure training should be organised from time to time. The findings in all items in the questionnaire revealed positive changes in trainees' behaviours during training when compared at the beginning and in the next quarters of training session.

Even though the training programme was useful in improving the participants' knowledge and skills, but it could not achieve the maximum objectives in selected aspects of the training. From the written and oral feedback, Pusat Ulul Albab should take up the challenge of improving the training aspects commented by the participants as would enhance a better outcome for what was already considered an established training programme using the QEI module approach. They shared a lot of interesting ideas that can be taken into 
consideration such as implementing new activities that could attract more participants to join the different phases of the programme. The module could also integrate new elements such as the application of new educational apps and platforms as seen in the social media sphere. Islamic contents should be made relevant with the changing educational and social landscape. With proper plan and implementation, the modules could be further strengthened and it could always be applied in other higher learning institutions as it has benefitted the first Ulul Albab QEI training participants in this university.

To conclude the results of this study and ensure the achievement of its objectives, the researchers analysed the feedback and responses of the sample of the study (students of Ulul Albab Centre, UPSI) who had undergone the programmes organised by the Ulul Albab Centre. The researchers divided students' responses into three sections according to the three elements, Quranic, Encyclopaedic and Ijtihadik (QEI). The researchers divided each pillar of this theory into four sections that students' responses focused on (contents, lecturers, performance, outputs). The following summary analysed the responses of the study samples on the three pillars of the theory.

- In the Quranic part, the trainees' opinion on it was very positive and confident. The degree of satisfaction with the programs of the Quranic section was the highest among the three pillars of the module (QEI). The participants' evaluation of the program ranged from $80 \%$ to $97 \%$ (Wahyu and Science). Their satisfaction level increased on the delivery and the satisfaction rate of the study samples began to increase on the performance of the Quranic module. The trainees' satisfaction in the first quarter of 2018 was $95 \%$ while in the fourth quarter of the same year was $97 \%$ on the content presented and the satisfaction rate on records and outputs of the programme stayed constant at $97 \%$.

- In the Encyclopaedic aspect, the results of the study showed that the most satisfactory aspect of the programme was the personality development programme-100\% of the study samples were satisficed about the programme. The other part of the Encyclopaedic aspect was the learning of foreign languages (Arabic and English). It suffered low satisfaction in the Arabic language on the part of the content presenter (lecturer)—with only $62.5 \%$ rating - and with $37.5 \%$ rating on the practical content aspect. At the end of the programme, the satisfactory level increased to $90 \%$ for the assessment on lecturer and $90 \%$ for the content. For the English language, it started with $80 \%$, and increased at the end of the programme to $90 \%$.

- The Ijtihadik aspect which focuses on the creative aspects of candidates and critical thinking as well as innovation and development was the third element of the programme. The responses of the candidates towards this component were high, and some of their responses reached $80 \%$-rated the lowest on this aspect for the content and later progressed positively during the last quarter of 2018. The satisfaction of the candidates was $90 \%$, while the content satisfaction rate reached $95 \%$ on the part of creativity, while the satisfaction with the innovation and development programme was slightly lower, reaching $80 \%$ in the first quarter of the year, and reaching $90 \%$ rate in the last quarter of 2018 , indicating the growing satisfaction of students with this module content.

\section{Conclusion}

The findings of this study have answered the research questions on the impact of the QEI module on teacher trainees' attitudes and personality traits that the effectiveness of the QEI Ulul Albab teacher training programme in UPSI was high in terms of improving the teacher trainees' confidence and skills. But in terms of critical thinking and innovation (the Ijtihadik module), the feedback given was on the need to have more training to provide teachers necessary level of skills and confidence for effective implementation in the teaching of the Ulul Albab students (high achiever students). The findings and sharing by the participants further revealed the needs to further improve the presentation of the QEI module for better overall understanding on the important aspects of the modules. The Quranic module is designed with a new interesting approach, but still require more credit hours to hone the skills among the trainees as it combined the Quran and science knowledge integration-a new concept to many trainees. Having expert trainers who can deliver the contents in interesting ways would present another challenge for Pusat Ulul Albab because the trainees might have their own preferred personalities or experts that meet the requirements as mentioned and listed in their feedback. The Quranic Module method of delivery should match the expectations of the trainees as it could present a tough challenge especially for those who come from conventional or national schools and have basic understanding of the Quran education and method of understanding.

This study is the first to examine the QEI theory for fostering outstanding Ulul Albab teacher trainees personality, and it differs slightly from the scope of the original QEI module taught among the existing school students. At university level, QEI is a programme designed to empower the Ulul Albab teacher trainees in the 
areas of this programme components of QEI (Quranic, Encyclopaedic and Ijtihadik). The results of this study showed that self-development which is part of the Encyclopaedic aspect in Ulul Albab programme is the most satisfactory part for the candidates. The researchers believed that this high level of satisfaction was due to the fact that the candidates are in their youth and they have a strong aspiration to grow as the role models in the society as well as their university mates. Students with high satisfaction rate in the content area, especially those in the first quarter of 2018 group, attributed this study results to the effectiveness of the content lecturers and the method of delivering the lessons in Arabic language. The method was very traditional, and the result began to change after changing the lecturer, content choice and presentation method. The programme of critical thinking and innovation was one of the programmes that received a low rating percentage in candidates' satisfaction and it could be attributed to the fact that these programs were new for all the students, which led to a lack of interaction with the trainer, as mentioned by the students' feedback at the end of this study. The researchers found that this programme's theory was enjoyable to the participants and effective in some respects to develop the teacher trainees' individual soft skills. In addition, the theory also covered some personality development aspects such as critical thinking, innovation and creativity which are useful to the university students not only in their study but also their personal life.

\section{Acknowledgment}

The researchers would like to thank USIM Research Management Centre for their assistance and support in this study. Special thanks and appreciation to Permata Insan College for allowing the participation of the school holiday camp and iLE active users in contributing their ideas, opinions and insights in making iLE a better teaching and learning management system. The researchers thank and acknowledge the Ministry of Education Malaysia for funding this research under the Fundamental Research Grants Scheme FRGS/1/2019/SS04/USIM/02/1 also the researchers never forgot to thank GENIUS Insan College in USIM for their support, unlimited assistance in the data collection, data analysis and facilitation of the task.

\section{References}

1. Abdullah, A. H. (2018). Program Ulul Albab: Satu Dimensi Baru dalam Pengembangan Pendidikan Islam di Negeri Terengganu. Scanned by CamScanner, (July 2008).

2. Ahmad Bazli, A. H., Zakaria, Z. \& Spawi, M. (2017). Pembinaan Modul Pendidikan Al-Quran untuk Pelajar Pintar Berbakat: Pendekatan di Kolej Permata Insan. Al-Qanatir International Journal of Islamic Studies. Vol. 5. No. 2.

3. Al Mekhlafi, A. M., \& Osman, M. E. T. (2019). The effect of a holistic school improvement model in enhancing school effectiveness in Oman. Malaysian Journal of Learning and Instruction, 16(2), 187-200.

4. Ab Amin, N. A. (2015). The Roles of "Pondok" in Developing Visionary Dā'i: A Case Study of Pondok Kandis, Kelantan. Unpublished degree dissertation. Universiti Sains Islam Malaysia. Nilai.

5. Benlahcene, A., Awang-Hashim, R., \& Kaur, A. (2020). Personal best goals: Do they mediate the relationship between teacher autonomy support and student engagement? Malaysian Journal of Learning and Instruction, 17(1), 25-49.

6. Daud, Z., \& KUIS (2018). Pelaksanaan Program Ulul Albab di MRSM: Satu Kajian Fakulti Pengajian Quran dan Sunnah Fakulti Pengajian dan Peradaban Islam Sumber. Majlis Amanah Rakyat Buku Rekod Malaysia, 2018 (Thiqah).

7. Fakhruddin, F. M., Ishak, C. C., \& Asmawati, S. (2020). Proses dan Kaedah Pembelajaran Tahfiz Dalam Kalangan Murid Di Sekolah Menengah Agama Kerajaan Di Malaysia (Process and Method of Tahfiz Learning Among Students in Malaysian Government Religious Secondary Schools). Malaysia. Malaysian Journal of Learning and Instruction, 17(2), 311-340.

8. Ibrahim, A. R., Saleh, N. S. S. N., Yusoff, N. M. R. N., Kamarudin, M. Y., \& Zakaria, Z. (2017). Enriching gifted and talented students via smart tablets. Advanced Science Letters, 23(5), 4848-4851. https://doi.org/10.1166/asl.2017.8925

9. Idris, Jusoh. 28 February 2013. "Program Ulul Albab: Ulul Albab-Misi Menjana Kepimpinan Muslim Global”. http://www.silveromedia.com.my/idrisjusoh/?page_id=501 dicapai pada 10 Disember 2019.

10. Islaieh, A. I. S., Jailani, M. R. M., Zainuddin, N., Kamaruddin, W. A. Z. W., \& Zakaria, Z. (2020). iLEinitiative: Interactive online platform in teaching and learning Arabic for gifted students. International Journal of Advanced Science and Technology, 29 (6 Special Issue), 1317-1328.

11. Kurikulum, J. J., \& Pasifik, P. A. Ulasan Sistematik: Program Ulul Albab dalam Sistem Pendidikan di Malaysia (2015). JuKu, 22-35., https://www.bharian.com.my/berita/pendidikan/2017/09/331659 /umt-lancar-studio-al-quran-ulul-albab-pertama-di-malaysia 
12. Lima MRSM Ulul Albab Baharu, https://www.hmetro.com.my/node/220421.

13. Mahasiswa, P., Islam, U., Uin, N., Aziz, R., \& Si, M. (2007). Pendidikan Ulul Albab Pada Mahasiswa Universitas Islam Negeri (Uin) Malang. Rahmat Aziz, M.Si, 2(1), 307-320.

14. Majid, H. A. (2017). Towards producing world leaders based on the worldview of al-Quran, encyclopaedia and ijtihad to become an agent of change, 2 (Dis), 28-64.

15. Mohamed, N. (2012) Program Ulul Albab Suatu Proses Tranformasi Pendidikan Malaysia: Kajian Kes Sekolah Menengah Imtiaz, Terengganu 1, (April 2012), 111.

16. Nasri, N. M., Halim, L., Asyraf, M., \& Talib, A. (2020). Self-directed learning curriculum: Students' perspectives of university learning experiences. Malaysian Journal of Learning and Instruction. 17(2), $227-251$.

17. Shahril, M., \& Ahmad, B. (2013). Integrating Ulul Albab Education and Science Education in the development of Insan Ta'dibi generation: A Case Study of MARA Junior Science College (MJSC), 96103.

18. Subirin, N. A., Alwi, N. H., Fakhruddin, F. M., Kalthom, U., Manaf, A., \& Salim, S. S. (2017). Ulul Albab Generation: Roles of Ulul Albab Teachers in Malaysian Selected School, 7, 190-191. https://doi.org/10.6007/IJARBSS/v7-i14/3793.

19. Tahfiz Model Ulul Albab jadi tumpuan, http://www.utusan.com.my/mega/agama/tahfiz-model-ulul-albabjadi-tumpuan-1.817434.

20. Thambu, N., Othman, M. K. H., \& Naidu, N. B. M. (2020). Using forum theatre to develop various levels of thinking skills among moral education students in secondary school. Malaysian Journal of Learning and Instruction, 17(2), 167-194.

21. Thinwiangthong, S., Eddy, C. M., \& Inprasitha, M. (2020). Mathematics teachers' abilities in developing formative assessment after the introduction of lesson study and open approach innovations. Malaysian Journal of Learning and Instruction, 17(1), 101-132.

22. Zailani, Z., \& Bakar Karsae, A. (2018). The Thinking of Islamic Education Renewal In The Perspective Of Mr. Haji Sulong Al-Fathoni. Intiqad: Jurnal Agama dan Pendidikan Islam, 10(2), 349-372. https://doi.org/10.30596/intiqad.v10i2.2325.

23. Zainal Abidin, M. Z. H., Ismail, H., Hassan, P., Yusof @ Salleh, M. Y., Mohd Noh, Abd. M., \& Mohd Noor, A. F. (2020). Modernizing Education System in Pondok Sungai Durian, Kuala Krai, Kelantan. Jurnal Intelek, 15(1), 40-47. https://doi.org/10.24191/ji.v15i1.265

24. Zakaria, Z., Md Sallehan, S., Wan Kamaruddin, W.A.Z., Ahmad Hilmi, A. B. \& Islieh, A.R.S. (2018). Challenges in Early Quran Education: Identifying Factors that Affect Permata Insan Summer Camp Students' Performance. Sains Insani. https://oarep.usim.edu.my/jspui/handle/ $123456789 / 5079$. 